\title{
TNFRSF10D Gene
}

National Cancer Institute

\section{Source}

National Cancer Institute. TNFRSF10D Gene. NCI Thesaurus. Code C159371.

This gene plays a role in the inhibition of apoptotic signaling. 